\title{
Endoscopic-ultrasound evaluation and fine needle aspiration with a linear echoendoscope in the cecum: it is possible
}

Endoscopic ultrasound (EUS)-guided fine needle aspiration (FNA) is central to the accurate diagnosis of subepithelial lesions. Similarly, staging of early neoplastic lesions is also an important step in deciding the best treatment option [1, 2]. Unfortunately, the oblique endoscopic view of the linear-array echoendoscope precludes routine cecal intubation. Therefore, EUS evaluation in the right coIon and cecum is usually restricted to mini-probes and forward-view radial echoendoscopes, which do not allow tissue sampling [3]. We describe a new technique that allows a standard oblique-view linear-array echoendoscope to be used to intubate the cecum and perform EUS-FNA.

We employed a combined overtubeguidewire technique. Firstly, we placed a colonic hydrophilic-coated flexible steelcoiled overtube (Entrada; US Endoscopy) over a standard colonoscope (CF-Q150; Olympus). We then performed a colonoscopy and placed a guidewire (Jagwire; Boston Scientific) into the cecum. The colonoscope was pulled out leaving the guidewire in place. Next, we inserted a standard linear-array echoendoscope (GF UCT-180; Olympus) over the guidewire and through the overtube. Once the colon had been reached, the scope was carefully inserted using the guidewire to secure cecal intubation. Finally, ultrasound interrogation of the subepithelial lesion and EUS-FNA were successfully performed ( $\downarrow$ Video 1 ). In our second patient, we used the same technique to stage an early neoplastic lesion ( Video 1).

Using a colonoscope to straighten the sigmoid loops is an important step in correct placement of the overtube. Ulti-

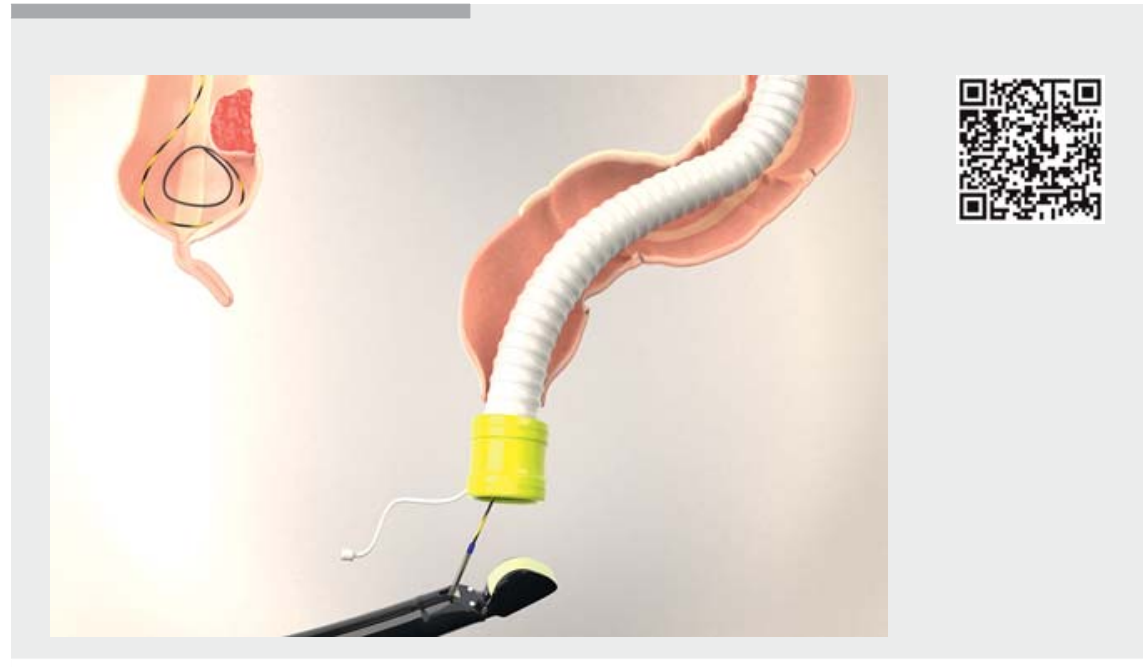

Video 1 The combined overtube-guidewire technique using a linear-array echoendoscope for endoscopic ultrasound-guided evaluation and fine needle aspiration of a cecal subepithelial lesion (Case \#1) and for staging of an early neoplastic lesion (Case \#2).

mately, this will allow the echoendoscope to safely reach the descending colon. The next step is the placement of a guidewire into the cecum. This guidewire directs the echoendoscope, helps widen the colonic flexures, and safeguards passage of the scope into the ascending colon and cecum.

EUS-FNA of right colonic submucosal tumors nevertheless remains challenging, but the aforementioned technique seems feasible and reproducible. It may further facilitate the management of subepithelial lesions in the right colon.

Endoscopy_UCTN_Code_TTT_1AS_2AZ

\section{Competing interests}

None
The authors

Spencer Cheng ${ }^{1}$, Vitor Ottoboni Brunaldi ${ }^{1}$, Gustavo Luis Rodela Silva ${ }^{1}$, Carlos Kiyoshi Furuya', Mauricio Kazuyoshi Minata', Sergio Eiji Matuguma ${ }^{1}$, Everson Luiz de Almeida Artifon ${ }^{2}$

1 Gastrointestinal Endoscopy Unit, Gastroenterology Department, University of São Paulo Medical School, São Paulo, Brazil

2 Department of Surgery, University of São Paulo Medical School, São Paulo, Brazil

Corresponding author

Vitor Ottoboni Brunaldi, MD, MSc Hospital das Clínicas - University of São Paulo Medical School, Dr. Arnaldo Av, 455, 01246-903, São Paulo, Brazil vitor.brunaldi@usp.br vbrunaldi@gmail.com 


\section{References}

[1] Haji A, Adams K, Bjarnason I et al. High-frequency mini probe ultrasound before endoscopic resection of colorectal polyps - is it useful? Dis Colon Rectum 2014; 57: 378 382

[2] Brunaldi VO, Coronel M, Chacon DA et al. Subepithelial rectal gastrointestinal stromal tumor - the use of endoscopic ultrasoundguided fine needle aspiration to establish a definitive cytological diagnosis: a case report. J Med Case Rep 2017; 11: 59
[3] Diehl DL, Johal AS, Nguyen V-NH et al. Use of a forward-viewing echoendoscope for evaluation of $\mathrm{Gl}$ submucosal lesions. Gastrointest Endosc 2012; 75: 428-431

\section{Bibliography}

DOI https://doi.org/10.1055/a-0896-2086

Published online: 13.5.2019

Endoscopy 2019; 51: E270-E271

(C) Georg Thieme Verlag KG

Stuttgart · New York

ISSN 0013-726X

\section{ENDOSCOPY E-VIDEOS}

https://eref.thieme.de/e-videos

口回 Endoscopy E-Videos is a free Fection, reporting 回舴: on interesting cases and new techniques in gastroenterological endoscopy. All papers include a high quality video and all contributions are freely accessible online.

This section has its own submission website at

https://mc.manuscriptcentral.com/e-videos 